\title{
Goats and Cattle
}

\section{J. T. Fowler}

To cite this article: J. T. Fowler (1915) Goats and Cattle, Folklore, 26:2, 213-213, DOI: 10.1080/0015587X.1915.9718881

To link to this article: http://dx.doi.org/10.1080/0015587X.1915.9718881

曲 Published online: 01 Feb 2012.

Submit your article to this journal $\square$

Q View related articles $₫$ 


\section{BAPTISM FOLKLORE.}

After I had given her friend's baby clinical Baptism, a Speyside woman told me it must be put back to bed wearing the clothes in which it had been baptized, and, having thus taken its first post-baptismal sleep, it would be much better in health afterwards; and, in any case, baptism would do the child's health good, and not harm. The baby has since died.

RONald BURN.

\section{Goats and Catrue.}

I asked a large farmer here and he told me that it was considered good for cattle and sheep to have a goat with them, and that the smell keeps off diseases and promotes good condition. It appears to be a convention, at least from $13^{\text {th }}$ century, to represent pastoral scenes with sheep feeding on the ground, and a goat on his hind legs craning up to browse on a tree: in one case there are two, one eating the foliage, the other the bark of the tree. "Many persons keep goats in stables, with an idea that they are good for the health of horses. It is likely that they promote the good temper of their companions. Now, good temper and cheerfulness tend to health, and it is a fact that a horse often shows great attachment to a goat." 1

Winterton, Doncaster.

J. T. FOWLER.

\section{IVELSII FolKLore. \\ Cutling a Baby's Ear to Cure Rickets.}

Before the Neath magistrates an old woman was charged with cutting a baby's ear with a razor. The solicitor who appeared for

1 One Hundred and Twenty Plates illustratize of IVislory, wilh a short Descriftion annexed to cach Ilate, London, S.P.C.K., 1843.

IIn some places the presence of gonts is supposed to check abortion among cattle-ith Ser., Notes and Queries, ii. 534. In India monkey is kept in the stables as a means of protection for the horses. A commion proverb says: "The luck of the stable is on the head of the monkeg."-Ev.] 